\title{
Manufacturing Franchising and Enterprise Networks
}

\author{
L.E. Hayfron, A.S Carrie, U.S. Bititci, K.V. Pandya, \\ Department of Design, Manufacture and Engineering \\ Management, University of Strathclyde, 75 Montrose Street, \\ Glasgow, UK G1 $1 X J$ \\ Tel: +44 (0) 1415482254 Fax: +44 (0) 1415520557 \\ E-mail:lee.hayfron@dmem.strath.ac.uk
}

\begin{abstract}
Franchising is predominantly used in the service industry where it is increasingly becoming a major player in the world economy. This paper presents work on a project researching how this success can be transferred to the manufacturing industry and the contribution it can make towards manufacturing competitiveness and business expansion. The paper presents a distinction between manufacturing franchising and other enterprise networks. This is followed by a discussion of how franchising can fit into a particular type of network. The conclusion summarises the key points of this discussion.
\end{abstract}

Keywords

Manufacturing Franchising, Networks, Extended Enterprise, Virtual Enterprise, Self-controlled Networks, Licensing.

\section{INTRODUCTION}

Organisations are increasingly entering into associations with others, often known as networks, to satisfy common objectives, in response to industrial globalisation. 
There are different types of networks, and organisations will tend to enter into a particular kind of network relationship to suit their objectives. It is fair to say that when the initial common objectives change or are considerably altered, there may be high risk of conflict arising in the network.

\section{TYPES OF NETWORKS}

This paper refers to the type of networks identified by Riis (1997) identified. These are The Extended Enterprise, The Virtual Enterprise, and The Autonomous Network.

\subsection{The Extended Enterprise}

The extended enterprise is characterised by a dominating company who extends its view and scope of operation. It takes the lead and sets the pace. The relationships in the network are well structured and guarded by formal agreements. The automobile industry is an example. The dominant company depends to an extent on other members of the network for crucial aspects of the value systems such as distribution and logistics, and directs sales to customers. It needs to keep in close contact with the customer to ensure responsiveness.

\subsection{The Virtual Enterprise}

The virtual enterprise is characterised by complementary contributions from a number of different companies, where one company plays the role of a broker. An example is a consortium for a construction company consisting of architects, civil and construction engineers and suppliers The virtual enterprise looks for new markets and can organise itself to satisfy the market, even though it lacks the current capabilities. Since most virtual enterprises are operating in high-tech areas, an effective and swift product and service development process is the key to competitive advantage. The virtual enterprise is constantly looking for new markets. This puts it in the high uncertainty category.

\subsection{The Autonomous Network}

This network is characterised by the gradual emergence of predominantly informal relationships between companies with no extensive contract, but rather governed by more or less a code of conduct. New members can easily join the networks, while others may leave. An example is a confederation of newspaper publishers. This type of network mainly consists of members who deal directly with consumers. In other words the value chain is shorter. 


\section{MANUFACTURING FRANCHISING}

Manufacturing franchising is a means by which manufacturers can establish smallscale facilities in new markets with a minimum of delay and capital outlay. The desire of the franchisor to be able to respond quickly to market changes, by having localised production units and the financial rewards that come with this competitive advantage, can be the driving force behind manufacturing franchising. (Hayfron et al, 1998).

Manufacturing Franchising is defined as the granting of a license by one party (the franchisor) to another (the franchisee) which entitles the latter to customise, manufacture, market, distribute and/or support goods and/or services, whereby the franchisor agrees to provide central commercial and technical support, and imposes the obligation to conduct a business in accordance with the Franchisor's concept for the term of a written franchise agreement.

The main characteristics of franchising as indicated in Carrie et al., (1998), include the following:

- The franchisee uses the Franchisor's trade name, know-how, procedural system, and other industrial and/or intellectual property rights.

- The franchisor provides training for the franchisee and his/her staff.

- The franchisee makes up-front and periodic management services payment to the franchisor.

- The franchisor provides management, marketing and accounting advice and services.

- The franchisor undertakes research into processes and business methods.

- The business relationship is between legally and financially separate independent undertakings and is not a transaction between a holding company and its subsidiary (as defined in section 736 of the Companies Act 1985) or between subsidiaries of the same holding company or between an individual and a company controlled by that individual.

Duckett (1997) identified five key features a business must have to ensure the success of a franchise:

- a recognised name, image and system

- a business format that can be easily duplicated

- a pilot operation to establish a proven format

- a sufficiently profitable business to satisfy the franchisor and franchisee

- a compatible motivations 


\subsection{Manufacturing Franchising and Licensing}

For reasons of clarity manufacturing franchising will be differentiated from licensing. This is because licensing is the closest to manufacturing franchising in terms of characteristics. Both licensing and franchising involve granting the right to use a particular production process or technology by one party to another, with limitations on how far they can be exploited for a fee. The licensor does not provide a complete blueprint. The licensee has to develop the use of the licensed technology (Carrie et al., 1998). The licensor does not provide support systems or initial training. The level of control over the licensed product is not as stringent as in franchising.

Some authorities view manufacturing franchising as just another form of industrial licensing. The key concept of manufacturing franchising is that the company processes, both physical and managerial should the have capability of being reproduced in a different market and operated by trained personnel other than those of the franchisor. It also requires the provision of on-going operational support by the franchisor to the franchisee in exchange for initial and on-going management fees. These concepts, together with the characteristics of franchising mentioned above distinguish it from licensing.

\section{FRANCHISING AND NETWORKS}

As Riis (1997) noted, a network can be used to describe any system consisting of cooperating companies. From the definition and characteristics of manufacturing franchising given above, it can clearly be described as form of network. Close cooperative initiatives between firms, (franchisor and franchisees) and co-operation among strategic business units of the individual players of the network, is central to the concept of franchising. Franchising is a form of co-operation between firms that can enhance both the internal and external value adding capability of the organisation.

This paper will attempt to fit manufacturing franchising into one of the networks mentioned, or conclude that the franchise relationships are so unique that a different type of classification is required

\subsection{Franchising and The Extended Enterprise}

In the extended enterprise, there is cooperation between firms carrying out different activities within the same general process. Firms operate at different points in the supply chain (Busby and Fan, 1993). While there is close cooperation in franchising, in most cases the franchisees will be operating at the same point in the supply chain. The franchisor may be operating at different points of the supply chain, but in any case will organise and control the whole network. 
The extended enterprise and franchising can enable agility. Agile manufacturing is a means of customising products to meet the diverse needs of customers. An agile manufacturer must be able to compete on quality, delivery, flexibility and price. Agile manufacturing favours smaller scale, modular production facilities, and co-operation between enterprises, where members of the network will be operating locally whilst ensuring a true synergy between themselves. These are features of an extended enterprise and also of franchising.

Another characteristic of the extended enterprise is that one company, usually the OEM, dominates the network. Manufacturing franchising fits closely with this notion, because the franchisor sets out specifically the scope of operation and decides who joins the network. The franchisor dominates the network but encourages the flow of information and ideas from every member of the network.

The franchisor undertakes research into processes and business methods on behalf of the whole network for an up-front and periodic management service payment made by the franchisees. The franchisor also provides management, marketing and accounting advice and services for a fee. While cooperating firms within the extended enterprise may rely on the dominating firm to carry out research, all other members of the network may be undertaking their own individual research.

\subsection{Franchising and The Virtual Enterprise}

The virtual enterprise consists of complementary firms pulling together each other's core competencies for the benefit of the whole network. One company plays the role of a broker. In franchising, the franchisor can be seen as playing the role of a broker. The franchisor organises the supply chain on behalf of the network as well as negotiating deals and bulk purchases for the network.

Unlike franchising, there is no clear leader or dominating company in the virtual enterprise. Most virtual enterprises are formed because the cost of research and development is too high for one company to handle. Each member's core competence is pulled together for the benefit of all. Product design and development are core competencies of the virtual organisation (Dean and Carrie, 1998).

The virtual enterprise may be vulnerable and unstable, because its success depends on members of the network delivering their agreed contribution. One partner may jeopardise the successful completion of the project. The cooperation in the virtual enterprise is built on trust rather than contract law (Dean and Carrie, 1998). This risk factor presents itself in franchising. One franchisee failing to maintain quality levels can put the whole network under risk of failure. However, unlike the virtual enterprise, the franchisor ensures the franchise agreement places a duty on the franchisee to exercise careful quality control over any products or components it sources. 


\subsection{Franchising and The Autonomous Network}

Riis (1997) describes the Autonomous Network as the gradual emergence of predominantly informal relationships between companies with no extensive contract. Franchising will clearly not fit this type of network because the relationship is formal under the franchise contract for a given period. The franchisor determines who can join the network and the scope of operation.

Table 1 below is a summary of the characteristics of the types of networks presented above. The characteristics chosen are only a summary and it is based on literature reviews. An explanation of each characteristic will be given:

- Dominant Company - does one company dictate the scope of operation?

- Agility - what is the market demand and how can this be achieved?

- Procedure Replication - is this is a key concept in the formation of the network?

- Self-Competition -are members allowed to compete with each other?

- Formal Procedures and Structures - what is the level required for the network to function?

- Core Competency Dependence - do members have different core competencies?

- Shared R\&D - do members actively participate in shared R\&D?

- Payment of Establishment Costs - do members pay costs of establishing their business or receive assistance from the network founder?

- High Uncertainty - what are the levels of uncertainty?

- Strong Relationships - is this a requirement the network success?

\section{CONCLUSION}

The paper has shown that manufacturing organisations can set up a network of focussed manufacturing units to satisfy the diverse needs of customers. The paper identified three types of networks. Manufacturing franchising has certain unique features, which distinguish it from other types of business expansion. Manufacturing franchising fits more closely into the extended enterprise category of networks than the virtual enterprise and the self-controlled network. There is a case for suggesting that organisations will not always fit a particular type of network, but have characteristics that can be broadly be linked to a particular type of network classification. Franchising can be seen as a type of extended enterprise network, comprised of self-employed partners and dominated by a single partner, who dictates the shape and scope of the network via legal means but allows for local considerations. Manufacturing franchising deserves more attention as a means of business expansion. 
Table 1 Summary of Characteristics of Networks

\begin{tabular}{|c|c|c|c|c|}
\hline & 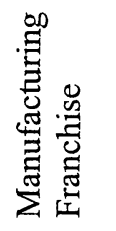 & 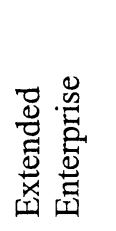 & 焉营 & 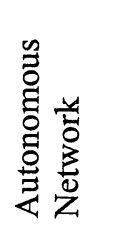 \\
\hline Dominant Company & $\sqrt{ } \checkmark$ & $\sqrt{ } \checkmark$ & $x x$ & $x \times x$ \\
\hline Agility & $\sqrt{ }$ & $\checkmark \checkmark$ & $\checkmark \checkmark$ & - \\
\hline Procedure Replication & $\sqrt{ } \checkmark$ & $\sqrt{ }$ & - & $x \times$ \\
\hline Self- Competition & $\times \times x$ & $\checkmark$ & $\sqrt{ } \sqrt{ }$ & $\sqrt{ } \sqrt{ }$ \\
\hline Formal Procedures \& Structures & $\sqrt{ } \checkmark$ & $\checkmark \checkmark$ & $\checkmark$ & $\checkmark$ \\
\hline Core Competency Dependence & - & $\checkmark \checkmark \checkmark$ & $\sqrt{ } \sqrt{ }$ & $\sqrt{ }$ \\
\hline Shared R\&D & $x \times x$ & $\checkmark$ & $\checkmark \checkmark \checkmark$ & - \\
\hline Payment of Establishment Costs & $\sqrt{ } \sqrt{ }$ & $\checkmark \checkmark$ & $\checkmark \checkmark \checkmark$ & $\checkmark \checkmark \checkmark$ \\
\hline High Uncertainty & - & $\checkmark$ & $\checkmark \checkmark \checkmark$ & $\checkmark$ \\
\hline Strong Relationships & $\sqrt{ } \sqrt{ }$ & $\sqrt{ } \sqrt{ }$ & $\sqrt{ } \sqrt{ }$ & $\sqrt{ }$ \\
\hline
\end{tabular}

Key: $\checkmark \checkmark \checkmark=$ extremely likely to be a characteristic. $\checkmark \checkmark=$ Very likely. $\checkmark=$ Likely. $-\mathbf{=}$ Might or might not be. $\mathbf{x}=$ Unlikely. . $\mathbf{x} \mathbf{x}=$ Very Unlikely.

$\boldsymbol{X} \times \mathbf{X}=$ Extremely unlikely.

\section{REFERENCES}

Busby, J.S. and Fan, I. S. (1993) The Extended Manufacturing Enterprise: Its nature and its needs, International Journal of Technology Management, 8(3-5), pp294-308

Carrie, A. S., Hayfron, L.E. and Dean, I. (1997), Manufacturing Franchising for Managing the Extended Enterprise, Organizing the Extended Enterprise, (Eds. P Schonsleben and A Buchel), IFIP Working Group 5.7 Working Conference, Ascona, Switzerland, pp111-120.

Dean, I. and Carrie A. S (1998) Future Enterprise Types and Strategies for Agile Manufacture, in Advances in Production Management Systems: Perspectives and future challenges (eds. N. Okino, H. Tamura and S Fujii), Chapman and Hall, pp115126.

Duckett, B. (1998), Challenges of turning a business into a franchise, The Franchise World Directory, 14th edition, Companion, pp47-50.

Hayfron, L.E., Carrie A.S., Bititci U.S., and Pandya K.V. (1998) Manufacturing Franchising: A Route to Agile Expansion, 5th EurOMA Conference, Scholl of Business Studies, Trinity College, Dublin, Ireland, 14-17 June, 
Riis. J.O. (1997), Correpondence to participants of the IFIP WG 5.7 Ascona Working Conference, Switzerland.

\section{BIOGRAPHY}

\section{Lee Hayfron}

Lee Hayfron is a Research Associate on the Manufacturing Franchising Research Project. He has a MSc degree in Information Systems Management.

\section{Professor Allan Carrie}

Allan Carrie is Professor of Manufacturing Systems at the University of Strathclyde $\mathrm{He}$ is a Chatered Engineer, Fellow of the IEE and of the RSA, a Senior Member of IEEE and a Member of IOM. He has industrial experience as an Industrial Engineer with Babcock and Wilcox in the UK and with Northern Electric in Montrel, Canada. He is the author of a book on simulation of manufacturing systems and over 130 papers. He served as a member of the Panel on Manufacturing, Production and Business Processes of the UK Technology Foresight Programme between 1994 and 1997. His main research interests are in computer aided production management and management of technology.

\section{Dr Umit Bititci}

Umit Bititci is the Director of Centre for Strategic Manufacturing and a Senior Lecturer at the University of Strathclyde. He is also a Chartered Engineer and member of the Institute of Operations Management. Umit is actively involved in a number of project management and consultancy assignments, with major blue chip companies. Umit's current research and development areas include Business Operations and Information Strategy as well as Performance Measurement and Management.

\section{Dr. Kaushik Pandya}

Kaushik Pandya is a Lecturer at the University of Strathclyde's Design, Manufacture and Engineering Management Department. He is a Chartered Engineer and a corporate member of the Institute of Electrical and Electronics Engineers, Institute of Operations Management and of the Institute of Business Process Re-engineering. His main responsibility is the development of lectures and research in Operations Management and related fields. He has published his work at national and international levels. 